\title{
Identification of Ralstonia solanacearum resistant rootstocks for tomato grafting
}

\author{
Kanyua Stella $^{* 1}$, Mwangi Maina ${ }^{1}$ and Mbaka Jesca. ${ }^{2}$ \\ ${ }^{1}$ Department of Agricultural Science and Technology, Kenyatta University, Kenya. \\ ${ }^{2}$ Horticulture Research Institute, Kenya Agricultural and Livestock Research Organization, Kenya \\ *Corresponding author email: ignastella@gmail.com
}

Key words: Bacterial wilt, Germplasm, Tomato, Grafting

Publication date 31/03/2020, http://m.elewa.org/Journals/about-japs/

\section{$1 \quad$ ABSTRACT}

Bacterial wilt, caused by Ralstonia solanacearum, causes severe losses to tomato (Solanum lycopersicum $L$ ). Current management measures are not fully effective. Grafting with resistant rootstocks may be an effective strategy for managing the disease. However, $R$. solanacearum populations maintain considerable diversity, and little information is known regarding the efficacy of available rootstocks for use in grafting to reduce bacterial wilt incidence and subsequent crop loss. Tomato belongs to family Solanaceae which includes other well-known species, such as eggplant (aubergine), peppers, tobacco and potato. The objective of this study was to identify bacterial wilt resistant germplasm that can be used as rootstocks in tomato grafting. The potential candidates for the study included species that belong to solanaceae family. Rootstocks included tomato cultivar Mt56, Eggplant (Solanum melongena), Capsicum and Sodom apple (Solanum incarnum). Tomato cultivars Anna F1 and Cal J were used as sources of scions. Diseased plants were collected from farmers' fields and bacterial inoculum isolated using CPG Medium with TZC used to identify distinct colonies of R.solanacearum. The inoculum was applied on the test plants by injecting into the soil planted with tomatoes. Disease severity data was recorded using 0 to 5 scoring scale. Data was subjected to ANOVA using Genstat version 15 and significantly different treatment means separated using LSD at $\mathbf{P} \leq 0.05$. Solanum melongena, Solanum incarnum and tomato cultivar (Mt56) did not develop infection while tomato cultivar Anna F1 and Cal $\mathrm{J}$ (used as positive controls) and Capsicum developed infection. It was concluded that resistant germplasm to bacterial wilt exists and can be utilized to graft susceptible tomato cultivars and contribute to management of bacterial wilt.

\section{INTRODUCTION}

Bacterial wilt (BW) caused by Ralstonia solanacearum is one of the most destructive diseases of solanaceous plants (Mansfield et al., 2012). The disease has a worldwide distribution, affecting crop production in tropical, subtropical, and temperate regions (Martin and French, 1985; Muthoni et al., 2012). R. solanacearum persists in soil, weeds, plant debris, rhizospheres, and alternate hosts. It spreads through irrigation water or infected planting material, thus hindering pathogen eradication (Hayward, 1991; Laferriere et al., 1999; Liu et al., 2016). When living freely in the soil, $R$. solanacearum occurs in a motile form to efficiently find and invade the host through chemotaxis and aerotaxis (Yao and Allen, 2006, 2007). R. solanacearum generally enters through wounded roots or natural openings and it infects the intercellular space of the root cortex and vascular parenchyma. It can also invade 
xylem vessels and spread to the stem and leaves, where bacterial cell density can reach up

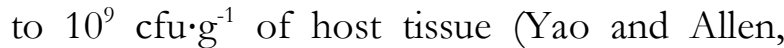
2006; Álvarez et al., 2010). At this stage, a cell density-dependent (i.e., quorum sensing) conversion occurs from a motile phenotype to a non-motile virulent phenotype, adapted to a plant parasitic lifestyle (Tans-Kesrten et al., 2004). Several resistant rootstocks have been identified and used to control bacterial wilt. However, bacterial wilt has been reported in commercial tomato cultivars grafted on resistant rootstocks in Korea and Japan (Lim et al., 2008; Nakaho et al., 2000). Therefore, there is need to select new resistant germplasm for use in grafting to control bacterial wilt. Grafting is the art of joining together two plant parts (a rootstock and a scion) by means of tissue regeneration, in which the resulting combination of plant parts achieves physical reunion and grows as a single plant (Janick, 1986). Grafting has been used effectively for overcoming environmental stresses including salinity (Estan et al., 2005; Ruiz et al., 2005; Colla et al., 2006), extreme temperatures (Abdelmageed et al., 2004) Black et al., 2003),

\section{MATERIALS AND METHODS}

The experiment was conducted in the field at Kenyatta University Research and Teaching Farm. The selection criteria for rootstocks were based on botanical relationship to tomato (Solanaceae family) and using available literature. Candidate species included Solanum incarnum (Sodom apple), tomato variety Mt56, Capsicum (Capsicum annum sp. L) and Solanum melongena (Eggplant). Commercial tomato cultivars Cal J and Anna F1 were included in the experiment as positive controls. The seedlings of the selected rootstocks were raised on well prepared nursery beds and all the candidate species seeds were planted on the same day. The seedlings were raised for one month in the nursery. Transplanting was then done in polybags of dimensions $9 \mathrm{~cm}$ by $5 \mathrm{~cm}$ by $10 \mathrm{~cm}$ in sterile soil and manure (2:1) after three weeks in the nursery. Ralstonia solanacearum was and excessive soil moisture (Black et al., 2003). Vegetable grafting has also enhanced resistance to soil-borne pathogens such as fungi, bacteria, viruses and nematodes. It has been used in management of Fusarium wilt on watermelon (Rivero et al., 2003) and tomato (Rivard, 2006); and Verticillium wilt on melon (Bletsos, 2005), eggplant (Ioannou, 2001), tomato (Rivard, 2006) and potato (Tsror and Nachmias, 1995, Rivero et al., 2003, Tresky and Walz, 1997, Rahman et al., 2005, Draie, 2009). The cultivated tomato, Solanum lycopersicum L., belongs to the family Solanaceae, which includes more than 3000 species, occupying a wide range of habitats (Knapp, 2002). The Solanaceae contain many species of economic use, such as food (tomatoes, potatoes, peppers and eggplants), medicines (deadly nightshade, henbane, Datura) and ornamental purposes (petunias). The production and consumption of tomatoes has substantially increased worldwide. This study therefore aimed at finding bacterial wilt resistant germplasm that can be used in tomato grafting for management of Ralstonia wilt.

isolated from fresh symptomatic plants of naturally infected cultivar Kilele plants obtained from farmers' fields. The fresh symptomatic plants were cut into pieces of $10 \mathrm{~cm}$ long and cleaned using water to remove debris and soil particles. The infected stems were sterilized in $70 \%$ ethanol and then rinsed using sterile distilled water. The stem portions were then suspended in sterile distilled water for bacterial ooze to identify the pathogen (Ralstonia solanacearum). Selective medium for $R$. solanacearum isolation was prepared using Casamino acid - peptone - Glucose (CPG) medium (Champoiseau, 2008) consisting of Casamino acid (casein hydrolysate) -1.0g, Peptone $-10 \mathrm{~g}$, Glucose $-5 \mathrm{~g}$ and agar $17.0 \mathrm{~g}$ per liter. The solution was autoclaved for 15 minutes at $121^{\circ} \mathrm{C}, \mathrm{pH}$ adjusted to $6.5-7.0$ and the medium allowed to cool; Tetrazolium 
Chloride (TZC) was added in the media to identify pure colonies of $R$. solanacearum. Three weeks after transplanting, inoculation was done by drenching the potting media with the $R$. solanacearum suspension of $1.2 \times 10^{8} \mathrm{cfu} / \mathrm{ml}$ (Prior et al., 1998). The scoring scale for disease severity was 0 - 5; with 0 indicating no disease while 5 indicated all inoculated plants had 100\% infection. Pests and diseases such as downy mildew, early blight, late blight, anthracnose, leaf spot and powdery mildew were controlled using pesticides such as Imidacloprid (against whiteflies, thrips and aphids) and fungicides such as Metalaxy 1 - M + Mancozeb. Standard agronomic practices for tomato production were deployed and included; watering done

\section{$4 \quad$ RESULTS}

Colonies of $R$. solanacearum were visible after 48 hours of incubation at $28^{\circ} \mathrm{C}$. Colonies of the normal (virulent type) were pink colored, irregularly- round, fluidal and opaque three times a week and crop nutrition with NPK 23:23:0 (10gms per hole or $50 \mathrm{kgs} / \mathrm{ha}$ ) applied during transplanting, NPK 17:17:17 (10gms per hole or $50 \mathrm{kgs} / \mathrm{ha}$ ) used as top dressing fertilizer one month after transplanting, and foliar fertilizers .Boom flower ${ }^{\circledR}$ (Nitrobenzene) (1ml/ litre of water) at flowering alternated with Easy grow ${ }^{\circledR}$ and Calcium Nitrate used as foliar fertilizers at $2 \mathrm{~g} / \mathrm{L}$ of water. Inoculated plants were observed daily until appearance of the first wilt symptoms. Ten plants were used for each treatment and data on disease incidence was recorded based on the number of plants showing wilting symptoms.

(Champoiseau, 2008). Sub- culturing was done to get pure cultures which were used to prepare the inoculum used on experimental plants.
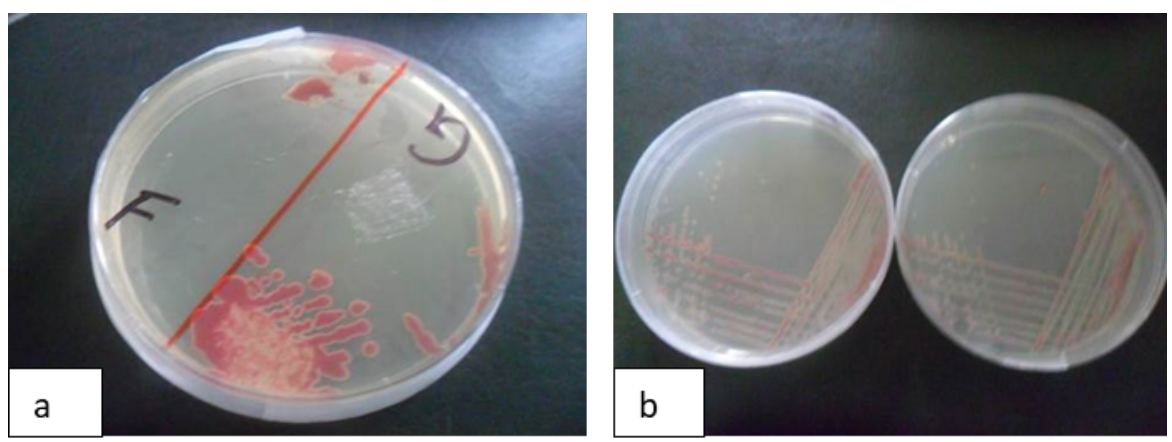

Plate 1: Isolated colonies of $R$. solanacearum on TZC Medium (a) (F - non-virulent and G - virulent colonies) and Sub- cultured colonies of R. solacearum (b).

During pathogenicity testing, Solanum melongena, Solanum incarnum and tomato Mt56 were not infected and thus were classified as resistant/tolerant. Tomato cultivars Cal J, Anna F1 and Capsicum showed wilting symptoms that were observed in week 2 and by week 5 plants had died (Table 1). Expression of symptoms on the Anna F1 and Cal J and Capsicum confirmed virulence of the bacterial isolate. 
Table 1: Mean number of surviving (uninfected) plants following inoculation with $\mathrm{R}$ solanacearum.

\begin{tabular}{lllll} 
Treatment & $\mathbf{7}$ days & $\mathbf{1 4}$ days & $\mathbf{2 1}$ days & $\mathbf{3 5}$ days \\
\hline Cal J & $10 \mathrm{a}$ & $2.7 \mathrm{a}$ & $5.0 \mathrm{a}$ & $0.0 \mathrm{a}$ \\
Capsicum & $10 \mathrm{a}$ & $2.3 \mathrm{a}$ & $4.3 \mathrm{a}$ & $0.0 \mathrm{a}$ \\
Anna F1 & $10 \mathrm{a}$ & $2.0 \mathrm{a}$ & $4.3 \mathrm{a}$ & $0.0 \mathrm{a}$ \\
Eggplant & $10 \mathrm{a}$ & $10.0 \mathrm{~b}$ & $10.0 \mathrm{~b}$ & $10.0 \mathrm{~b}$ \\
Mt56 & $10 \mathrm{a}$ & $10.0 \mathrm{~b}$ & $10.0 \mathrm{~b}$ & $10.0 \mathrm{~b}$ \\
Sodom apple & $10 \mathrm{a}$ & $10.0 \mathrm{~b}$ & $10.0 \mathrm{~b}$ & $10.0 \mathrm{~b}$ \\
\hline
\end{tabular}

NB: Values within column followed by same letter are not significantly different at $\mathrm{P} \leq 0.05$.

\section{DISCUSSION}

Using genetically resistant cultivars is the most effective and environmental-friendly method to control bacterial wilt. Several resistant rootstocks have been identified and used to control bacterial wilt (Sang et al, 2016). Therefore, selecting additional resistant sources can contribute to improved control of bacterial wilt. The findings of this study demonstrate resistant rootstocks can be an important component in integrated pest management of bacterial wilt on tomato. Quantitative resistance to diseases and pests in wild Solanum spp. is known to breeders but its utilization can be problematic because of associated unwanted traits, such as small fruit size (Opena et al.,

\section{$6 \quad$ Literature Cited}

Abdelmageed, A., H., A., Gruda, N., Geyer, B. (2004). Effects of Temperature and Grafting on the Growth and Development of Tomato Plants under Controlled Conditions. Rural Poverty Reduction through Research for Development and Transformation. Deutscher Tropentag 2004: 3p.

Álvarez, B., Biosca, E. G., and López, M. M. (2010). On the life of Ralstonia solanacearum, a destructive bacterial plant pathogen. Technol. Educ. Top. Appl. Microbial. Microb. Biotechnol. 1, 267-279.
1990; Walter, 1967; Wang et al., 1998). This study provides information of available rootstock sources that nursery operators can utilize in grafting to manage bacterial wilt in tomato. The resistance to bacterial wilt among potential rootstocks seen in this study and others (Freeman et al, 2009) could complement other integrated pest management strategies to reduce bacterial wilt incidence in severely infested soils. Further study is recommended to evaluate farmer preferred tomato cultivars when grafted onto the resistant rootstocks to determine disease reduction, compatibility and performance of the grafted plants.

Black, L., L., Wu, D., L., Wang, J., F., Kalb, T., Abbass, D., Chen, J., H. (2003). Grafting Tomatoes for Production in the Hot-Wet Season. International Cooperators Guide. Asian Vegetable Research \& Development Center (AVRDC) 03-551: 6p.

Champoiseau, P.G. 2008. R. solanacearum Race 3 biovar 2. In: Allen, C., Jones, J.B., Harmon, C. and Momol, T.M (editors) Ralstonia solanacearum race 3 biovar 2: Detection, exclusion and analysis of a Select Agent, Educational modules .University of Florida. 
https://plantpath.ifas.ufl.edu/rsol/Rals toniaPublications PDF/Rsolanacearum R3b2 PDF.pdf

Colla, G., Rouphael, Y., Cardarelli, M., Rea, E. (2006). Effect of salinity on yield, fruit quality, leaf gas exchange and mineral composition of grafted watermelon plants. HortScience 41: 622-627.

Draie, R. (2009). Effet du greffage sur la productivité de la tomate en conditions de non infestation et d'infestation par l'orobanche. Caractérisation d'une invertase acide, enzyme majeure de la force de puits du parasite. Thèse de Doctorat, Université de Nantes : 191p.

Estan, M., T., Martinez-Rodriguez, M., M., Perez-Alfocea, F., Flowers, T., J., Bolarin, M., C. (2005). Grafting raises the salt tolerance of tomato through limiting the transport of sodium and chloride to the shoot. Journal of Experimental Botany 56: 703-712.

Freeman, J., Rideout, S. and Wimer, A. (2009). Performance of grafted tomato seedlings in open-field production. Pages 45-41 to 45-42 in: 2009 Annu. Int. Res. Conf. Methyl Bromide Alternatives Emissions Reductions. San Diego, CA.

Hayward, A. C. (1991). Bacterial wilt caused by Pseudomonas solanacearum. Annu. Rev. Phytopathol. 29, 65-87. doi: 10.1146/annurev.py.29.090191.000433

Ioannou, N. (2001). Integrating soil solarization with grafting on resistant rootstocks for management of soil-borne pathogens of eggplant. Journal of Horticultural Science \& Biotechnology 76: 396-401.

Janick, J. (1986). Horticultural Science, 4th edn. W.H. Freeman \& Co., New York.

Knapp, S. (2002). Solanum section Geminata. Fl Neotrop 84:1-405

Laferriere, T. L., Helgeson, P. J. and Allen, C. (1999). Fertile Solanum tuberosum $+S$. commersonii somatic hybrids as sources of resistance to bacterial wilt caused by Ralstonia solanacearum. Theor. Appl. Genet.
98, 1272-1278. doi: $10.1007 / \mathrm{s} 001220051193$

Liu, T., Yu, Y., Cai, X., Tu, W., Xie, C., and Liu, J. (2016). Introgression of bacterial wilt resistance from Solanum melongena to S. tuberosum through asymmetric protoplast fusion. Plant Cell. Tissue Organ. Cult. 125, 433-443. Doi: 10.1007/s11240-016-0958-9

Lim, Y.-S., Lee, M.-J., Cheung, J.-D., Rew, Y.H. and Kim, B. - S. (2008). Occurrence and biovar classification of bacterial wilt caused by Ralstonia solanacearum in eggplant (Solanum melongena). Res. Plant Dis. 14:10-14 (in Korean).

Mansfield, J., Genin, S., Magori, S., Citovsky, V., Sriariyanum, M., Ronald, P. (2012). Top 10 plant pathogenic bacteria in molecular plant pathology. Mol. Plant Pathol. 13, 614-629. doi: 10.1111/j.1364-3703.2012.00804.x

Martin, C. and French, E. (1985). Bacterial Wilt of Potato: Pseudomonas solanacearum. Lima Available at: https://betuco.be/Potato/Bacterial Wilt of Potato - Ralstonia solanacearum.pdf

Muthoni, J., Shimelis, H. and Melis, R. (2012). Management of bacterial wilt [Ralstonia solanacearum Yabuuchi et al., 1995] of potatoes: opportunity for host resistance in Kenya. J. Agric. Sci. 4, 64 78. doi: 10.5539/jas.v4n9p64

Nakaho, K., Hibino, H. and Miyagawa, H. (2000). Possible mechanisms limiting movement of Ralstonia solanacearum in resistant tomato tissues. J. Phytopathol. 148:181-190.

Opena, R., Hartman, G. L., Chen, J., and Yang, C. 1990. Breeding for bacterial wilt resistance in tropical tomato. Pages 4450 in: 3rd Int. Conf. Plant Prot. Trop. Genting Highlands, Malaysia.

Prior, P., Allen, C. and Elphinstone, J. G (editors) (1998). Bacterial Wilt Disease Molecular and Ecological Aspects. Pub; 
Springer - Verlog Berlin Heidelberg, New York

Rahman, M. A., Rashid, M. A, Salam, M. A., Masud, M. A. T., Masum, A. S. M. H., Hossain, M. M. (2002). Performance of some grafted eggplant genotypes on wild Solanum root stocks against rootknot nematode. Journal of Biological Sciences 2: 446-448.

Rivard, C. L. (2006). Grafting tomato to manage soil borne diseases and improve yield in organic production systems. MSc thesis, North Carolina State University, USA.

Rivero, R. M., Ruiz, J. M., Romero, L. (2003). Role of grafting in horticultural plants under stress conditions. Food, Agriculture \& Environment, 1(1): 70-74.

Ruiz, J. M., Blasco, B., Rivero, R. M., Romero, L. (2005). Nicotine-free and salttolerant tobacco plants obtained by grafting to salinity-resistant rootstocks of tomato. Physiologia Plantarum 124: 465- 475 .

Sang, G. K., On-Sook, H., Na-Young, R., HoCheol, K, Ju-Hee, R., Jung, S. S., Kyoung-Yul, R., Sok-Young L., and Hyung, J. B. Evaluation of Resistance to Ralstonia solanacearum in Tomato Genetic Resources at Seedling Stage. Plant pathology Journal, 32(1): 58-64

Tans-Kesrten, J., Huang, H. and Allen, C. (2004). Ralstonia solanacearum need motility for invasive virulence on Tomato. EPPO Bull. 34, 173-178. doi: 10.1128/JB.183.12.3597

Tresky, S. and Walz, E. (1997). Testing solutions for control of bacterial wilt in tomatoes. Organic Farming Research Foundation Bulletin 4: 8-9.

Tsror, L. L., Nachmias, A. (1995). Verticillium wilt comparison of the tolerance phenomenon in potato to Ve gene resistance in tomato. Plant Sciences 43: 315-323.
Walter, J. M. (1967). Hereditary resistance to disease in tomato. Annu. Rev. Phytopathol. 5:131-160.

Wang, J. F., Hanson, P., and Barnes, J. (1998). Worldwide evaluation of an international set of resistance sources to bacterial wilt in tomato. Pages 269- 275 in: Bacterial Wilt Disease: Molecular and Ecological Aspects. P. Prior, C. Allen, and J. Elphinstone, eds. Springer, Verlag, Berlin.

Yao, J. and Allen, C. (2006). Chemotaxis is required for virulence and competitive fitness of the bacterial wilt pathogen Ralstonia solanacearum. J. Bacteriol. 188, 3697-3708. doi: 10.1128/JB.188.10.369

Yao, J. and Allen, C. (2007). The plant pathogen Ralstonia solanacearum needs aerotaxis for normal biofilm formation and interactions with its tomato host. $J$. Bacteriol. 189, 6415-6424. doi: 10.1128/JB.00398-07 